\title{
Horizontal distribution of Cladocera in a subtropical lake marginal to a river
}

\author{
Rafael CAMPANELLI MORTARI, ${ }^{1}$ Raoul HENRY ${ }^{*}$ \\ ${ }^{1}$ Paulista University (UNIP), Bauru, São Paulo State; ${ }^{2}$ Department of Zoology, Institute of Biosciences of Botucatu, São Paulo State \\ University (UNESP), Botucatu, São Paulo State, Brazil \\ *Corresponding author: rhenry@ibb.unesp.br
}

\begin{abstract}
Various abiotic and biotic factors may determine the spatial distribution patterns of Cladocera in a lake. The aim of this study was to examine the horizontal distribution of Cladocera in a lake connected to a river during low and high water phases and the abiotic factors that determine variation in their populations. Microcrustaceans were collected in integrated samples at 40 sites distributed on a lake. The mean abundance of Cladocera was around five times higher in the low water phase than in the high water phase. Only populations of Bosmina hagmanni Stingelin, 1904 and Bosminopsis deitersi Richard, 1895 predominated in the low water phase, while in the high water phase, B. hagmanni, Ceriodaphnia cornuta $f$. rigaudi (Sars, 1896) Diaphanosoma spinulosum Herbst, 1975 and Moina micrura Kurz, 1875 predominated at some sampling stations. The majority of cladoceran species showed an aggregated distribution in the low water phase, except $\mathrm{B}$. longirostris and $\mathrm{D}$. fluviatile and, B. longirostris, the only ones which presented a uniform distribution pattern in the high water phase. Most of the aggregates of cladoceran species predominated in both the dry and rainy periods on the east side of the lake due to intense easterly wind. Some cladoceran populations formed isolate aggregates in other parts of the lake and near the lake-river connection site. Canonical Correspondence Analysis (CCA) showed that the variables phosphorus, nitrogen and suspended matter (eutrophic conditions) determined distinct patterns of horizontal distribution in some cladoceran populations at some stations in the low water phase, while in others, the patterns of horizontal distribution were determined by environmental conditions as alkalinity, $\mathrm{pH}$, oxygen, depth and water transparency. In the high water phase, CCA revealed that phosphorus and water transparency were positive determining factors in the distribution of some cladoceran species, while alkalinity, depth and suspended matter were negative. Our study showed that the distribution of cladoceran species may vary somewhat between the two distinct water phases depending on the micro-scale variation patterns of environmental factors.
\end{abstract}

Key words: Spatial distribution; Cladocera; swarming; aggregation index; environmental factors; marginal lake.

Received: January 2015. Accepted: August 2015.

\section{INTRODUCTION}

Heterogeneous distribution of zooplankton in lakes in patches of varying sizes depends on concurrent abiotic and biotic processes, which makes up the so-called multiple driving forces hypothesis (Pinel-Alloul, 1995). Wind currents, internal seiches and vertical stratification are some of the abiotic factors determinant of horizontal distribution at a coarse scale, while vertical and horizontal migration, phytoplankton distribution patterns, predation by invertebrates and active swimming are the evocated biotic processes (Pinel-Alloul, 1995). At a fine scale, Langmuir circulation and physical gradients are the determining abiotic processes, and reproductive and swimming behaviors, co-active interactions, vertical migration and phytoplankton distribution are the biotic processes to which the formation of aggregates is attributed (Pinel-Alloul, 1995).

Micro-scale patches are actually observed in a lake's littoral zone and swarms of some zooplankton species are regulated by biotic processes (Malone and MacQueen, 1988). Four mechanisms may be mentioned as determining the formation of zooplankton patches: diel vertical migration, predator avoidance, food finding and mating (Folt and
Burns, 1999). Individual responses to mates, food and predators are small-scale processes in the formation of small zooplankton clusters, while horizontal and vertical migrations are large-scale processes in the formation of large micro-crustacean aggregates and swarms (Folt and Burns, 1999). Both intermediate scales (coarse and fine scales) of zooplanktonic aggregates are actually found in small lakes (Malone and McQueen, 1983; Pinel-Alloul, 1995).

Some papers have compared the distribution of microcrustaceans sampled in transects from lakes littoral to pelagic zones (Pinel-Alloul et al., 2004; Adamczuk and Mieczan, 2013). Others present sampling systems used along various littoral sites and in lake and reservoir limnetic zones (Bernot et al., 2004; Lazareva et al., 2013); however, studies on the simultaneous prevalence of Cladocera at both horizontal and vertical dimensions of lakes are relatively rare.

The region shaped by marginal lakes and rivers located in the confluence zone of tributaries into reservoirs forms an artificial wetland (Junk et al., 2014). The intensity of hydrological pulses in this area is greatly reduced due to the reservoir water volume functioning as a buffer system 
(Henry, 2005). This peculiar area presents a behaviour distinct from actual floodplains submitted to single or multiple hydrological pulses along the year. In the high water phase, water lateral inflow from the river determines water quality homogeneity in aquatic marginal environments (Thomaz et al., 2007; Granado et al., 2012) and in limnophase, in the zooplankton communities (Lansac-Toha et al., 2009). In a study on seasonal variation in four different annual periods with distinct hydrological situations, Panarelli et al. (2014) showed that cladoceran abundance was 10 times higher in the lake-river disconnection period in comparison to the connection period. Reduction in the lake volume promoted a concentration effect and eutrophic conditions which determined an increase in cladoceran abundance (Panarelli et al., 2014).

The aim of this paper was to examine the horizontal distribution of cladoceran populations in two distinct hydrological situations: i) in the low water phase at the end of the potamophase, when the marginal lake shows great reductions in volume and depth; and ii) in the high water phase, when the lentic environment presents contrasting dimensions in relation to the low water phase.

Considering that different factors may determine the formation of cladoceran patches in a lake, we sampled the assembly at fine scales in order to examine the variation in horizontal distribution in population densities and the correlated abiotic parameters. Our assumption was that different cladoceran populations present a similar distribution, considering the small dimensions of the lake studied.

\section{METHODS}

\section{Study area}

Camargo Lake, the selected study area, is a lake marginal to the Paranapanema River in its confluence zone with the Jurumirim Reservoir in São Paulo State, south eastern Brazil (Fig. 1 A,B). Although connected to the river, lake-river connectivity, defined as the exchange capacity between environments, varies during the year according to fluctuations in the lotic ecosystem water level. According to Henry (2005), Camargo Lake is small (area: $0.221 \mathrm{~km}^{2}$, maximum length: $1.22 \mathrm{~km}$, maximum width: $0.31 \mathrm{~km}$, perimeter: $3.1 \mathrm{~km}$, shoreline index: 1.85$)$ and is classified as a polymictic lake, but it may present temporary micro-stratifications in the afternoons (MoschiniCarlos et al., 1998). Few macrophyte stands are observed
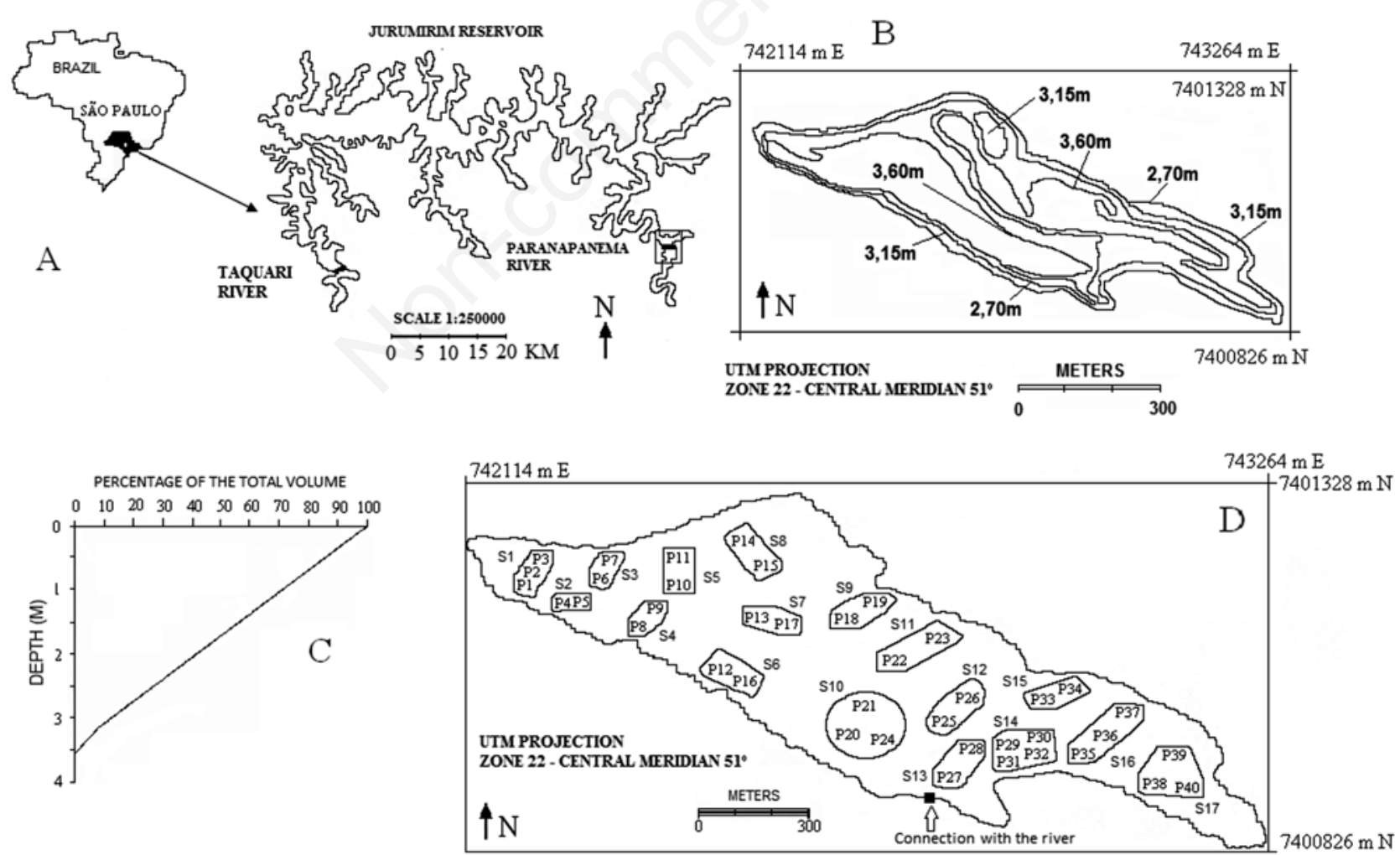

Fig. 1. Study area: Camargo Lake, located at the mouth zone of the Paranapanema River into the Jurumirim Reservoir, São Paulo, Brazil (A), bathymetric map (B), volume hypsographic curve (C) of the lake (according to Henry, 2005) and sampling site (P1 to P40) and station (S1 to S17) locations (D). 
in the littoral zone due to the lake bottom topography (Henry, 2005). Grass Echinochloa polystachya (H.B.K.) Hitchcok is observed along all the lake shores. Eichhornia azurea Kunth, a floating macrophyte, is distributed in diffuse stands by the lake, but more densely on the east side.

\section{Sampling procedure}

Environmental data and cladocerans were sampled at 40 sites distributed on the pelagic and littoral ( $3 \mathrm{~m}$ from the shore) zones of Camargo Lake (Fig. 1D) once in the dry (August 21, 2006) and once in the rainy (March 19, 2007) periods, corresponding to the low and high water phases, respectively. To determine the chemical and physical factors, samples were collected at the surface $(0.0 \mathrm{~m})$, in the middle and at the bottom $(0.5 \mathrm{~m}$ above the sediment) of the water column. At sites less than $1.0 \mathrm{~m}$ deep, sampling was limited to the surface.

The following variables were measured: i) water temperature with a Toho Dentam thermistor; ii) water transparency with a Secchi disk; iii) depth by sounding; iv) water alkalinity (Golterman et al., 1978), pH (through a Micronal Mod.B-380 pHmeter), conductivity at $25^{\circ} \mathrm{C}$ (with a Hatch Mod. 2511 conductivimeter), dissolved oxygen (Golterman et al., 1978), total nitrogen and phosphorus (Valderrama, 1981), suspended matter by gravimetry (Wetzel and Likens, 2000) and chlorophyll- $a$ (Golterman et al., 1978).

Rainfall data were obtained from a pluviometric station from the Water and Electric Power Department at Angatuba (São Paulo State, Brazil), about 25-km away from Camargo Lake. Water level data were provided by the Duke Energy - Paranapanema Company, and Camargo Lake volume variation was computed from the hypsographic curve (Henry, 2005) (Fig. 1C). The water level variation pattern is similar in both the dam zone and the confluence region of the Paranapanema River with the Jurumirim Reservoir (Pompêo et al., 1999). Information on wind direction and speed were supplied by the Brazilian Agency of Meteorology.

Cladocerans were sampled by vertical hauling a $50-\mu \mathrm{m}$ mesh net; a minimum of $100 \mathrm{~L}$ were filtered. However, at sites shallower than $1.0 \mathrm{~m}$ in the dry period, water was collected only from the surface. The collected organisms were fixed with $4 \%$ formaldehyde. A minimum of 150 organisms per sample were counted using a checkered acrylic chamber under a Carl Zeiss Stemi SV6 stereomicroscope. Abundance was expressed in ind $\mathrm{m}^{-3}$. Microcrustaceans were identified through the literature (Korinek, 1987; Smirnov, 1996; Elmoor-Loureiro, 1997; Orlova-Bienkowska, 1998; Hudec, 2000; Elmoor-Loureiro et al., 2004; Elmoor-Loureiro, 2007).

\section{Data analysis}

Firstly, the data from the 40 sites (P1 to P40) were grouped into 17 sampling stations (Fig. 1D). Grouping was shaped by site assemblages with no significant differences in abundance of cladoceran species. Differences were tested with $t$-student and ANOVA tests (Zar, 1996).

To determine the cladoceran horizontal distribution patterns, the mean crowding equation was used (Lloyd, 1967):

where

$$
\mathrm{x}^{*}=\mathrm{X}+\left(\mathrm{S}^{2} / \mathrm{X}-1\right)
$$

$\mathrm{x}^{*}=$ mean crowding, $\mathrm{X}=$ population mean and $\mathrm{S}^{2}=$ variance.

According to Mitchell and Williams (1982), linear regression between the mean crowding $\left(\mathrm{x}^{*}\right)$ and the mean density $(\mathrm{X})$ of the species supplied information on the zooplankton distribution patterns (uniform or patch distribution). Linear regression between the two variables $\left(\mathrm{x}^{*}\right.$ and $\left.\mathrm{X}\right)$ was computed through:

$$
x^{*}=a+b X
$$

where

$\mathrm{a}=$ constant, $\mathrm{b}=$ angular coefficient.

Linear regression angular coefficient data (b) determine the distribution patterns of cladoceran species and can be used as an aggregation index. A distribution pattern of a species in an aggregate formation occurs when $b>1$; when $b=1$, the distribution is heterogeneous uniform, and when $<1$, the specie distribution has an homogeneous uniform pattern.

The aggregation index was obtained using data on the total abundance of cladoceran. Species with abundance $<1 \%$ of the cladoceran assembly total abundance in either of the two periods studied were not computed into $b$.

Canonical correspondence analysis (CCA) relating taxa abundance and environmental variables for each period was applied in order to assess the correlations between cladoceran species and environmental factors. Before analysis, the data were $\log (\mathrm{x}+1)$ transformed.

\section{RESULTS}

A decrease in the Paranapanema River water level and a corresponding reduction in the lake volume were observed from April to November, 2006 (Fig. 2). In early September, 2006 the connection between the lake and the river was disrupted and Camargo Lake remained in limnophase for around four months. Then, intense precipitations from December, 2006 to January, 2007 caused an increase in the lake water level and volume and the association between the lacustrine ecosystem and the Paranapanema River was restored in the middle of December (Fig. 2). The lake remained thus connected to the river, in a potamophase, most of the year (from April to September, 2006 and, from December, 2006 to March, 2007). Wind history before sampling showed that the predominant direction was easterly and that the speed was higher in August when compared to March (Fig. 2). 
The highest mean maximum and Secchi disk transparency depth values were recorded in the high water phase and the highest suspended matter, total phosphorus and nitrogen values in the low water phase (Tab. 1). The highest water temperature and dissolved oxygen values were observed in the rainy and dry periods, respectively (Tab. 1). Water $\mathrm{pH}$ and alkalinity values were higher in the low water phase than in the high water phase and an inverse pattern was observed for conductivity (Tab. 1). In relation to chlorophyll-a, its values were higher in the dry period (Tab. 1).

Cladoceran assemblages were made up of 34 taxa, with 21 species in the dry period and 25 species in the rainy period. Only Bosmina hagmanni Stingelin, 1904 and Diaphanosoma fluviatile Hansen, 1899 were sampled in all sites in both periods. Variability of cladoceran assembly spatial abundance was observed (Fig. 3 A,B). In the dry period, the mean abundance of cladoceran $\left(82,085 \pm 29,203\right.$ ind $\mathrm{m}^{-3}$; range: $19,549-136,977$ ind $\left.\mathrm{m}^{-3}\right)$ was around five times as high as in the rainy period (17,571 $\pm 10,010$ ind. $\mathrm{m}^{-3}$, range: $6,508-42,668$ ind $\left.\mathrm{m}^{-3}\right)$. Cladocerans were abundant on the east side of the lake in both periods ((Fig. 3 A,B). Considering the total abundance, no apparent great variation was observed in the dry period, except a low abundance of cladoceran assembly at stations $\mathrm{S} 1$ and $\mathrm{S} 9$ (Fig. 3A). In the rainy period, high
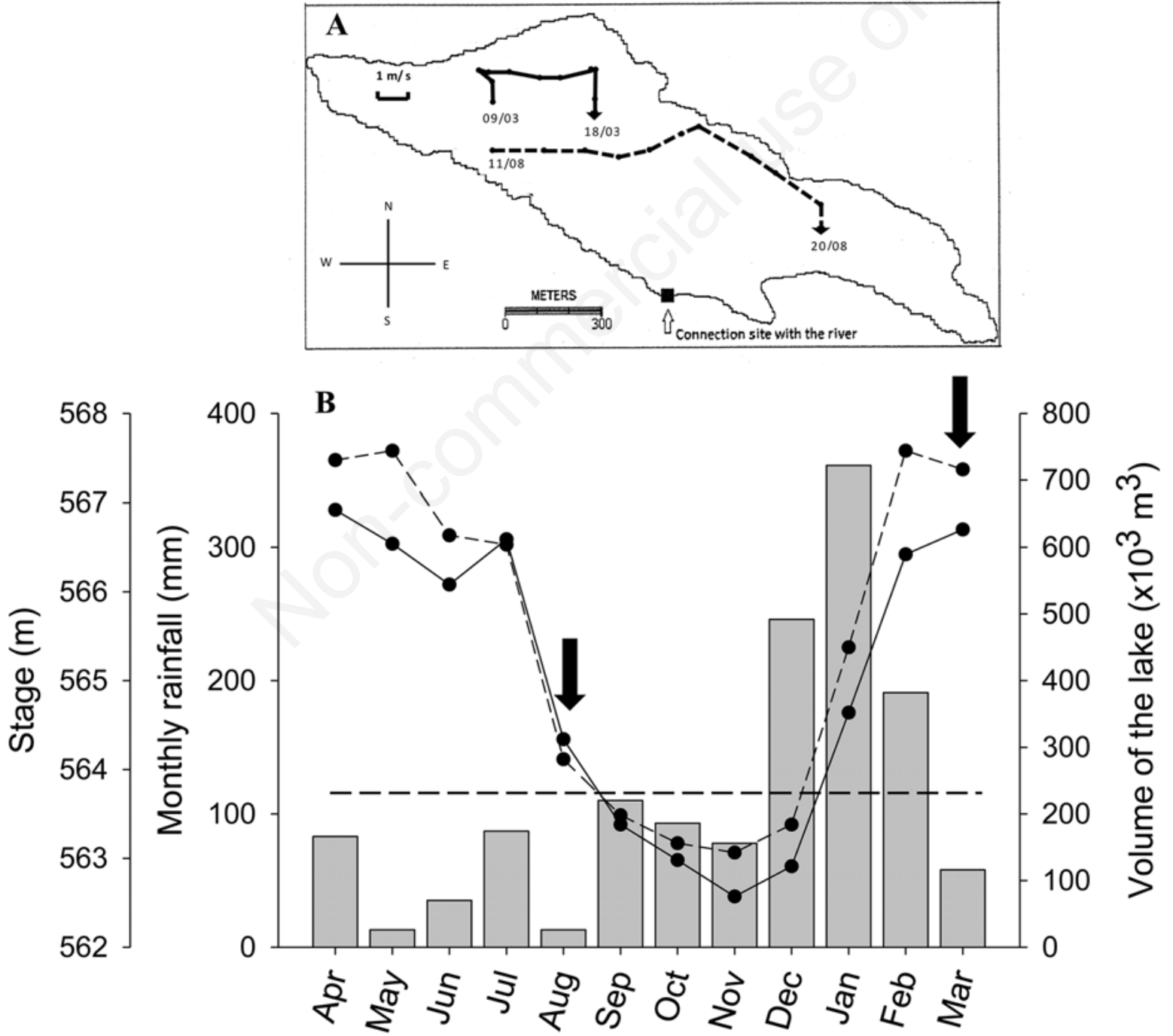

Fig. 2. Ten-day wind history before sampling (direction and daily mean speed) summarized in a progressive vector diagram in the low (August 2006) and high water (March 2007) phases and monthly water level variations (dashed line) (A); rainfall (bars) and volume (solid line) of Camargo Lake (the horizontal line represents the frontier $(563.60 \mathrm{~m})$ between connection, top, and isolation, bottom, of Camargo Lake to the Paranapanema River and the arrows indicate the sampling date) (B). 
abundance values were observed from stations S14 to S17 (Fig. 3B).

Concerning the relative abundance of cladoceran species in the low water phase, only populations of $B$. hagmanni, Bosmina longirostris (O. F. Muller, 1785), D. fluviatile and Bosminopsis deitersi Richard, 1895 were observed at all stations. The first three species showed a predominance trend on the east side of the lake and the fourth, to the west (Fig. 4A). Some species predominated in the high water phase: B. hagmanni (stations S6 and from S13 to $\mathrm{S} 17)$, Ceriodaphnia cornuta $\mathrm{f}$. rigaudi (Sars, 1886) (S3), Diaphanosoma spinulosum Herbst, 1975 (S1 and S5) and Moina minuta Hansen, 1899 (S2 and S12) (Fig. 4B). Differently from that observed in the dry period, $B$. longirostris and $B$. deitersi populations presented low relative abundances (Fig. 4B). According to the computed aggregation index, the cladoceran assembly presented a uniform distribution pattern in the low water phase and in the high water phase an aggregate distribution (Tab. 2), with predominant populations on the east side of the lake (Fig. 3). The majority of cladoceran species in Camargo Lake showed an aggregate distribution pattern in the dry period, except $B$. longirostris and $D$. fluviatile. In the rainy period, only $B$. longirostris presented a uniform pattern (Tab. 2). CCA analysis showed that, for the first axis, some species $(B$. hagmanni, B. deitersi, C. cornuta f. rigaudi, D. ambigua and $D$. fluviatile) correlated positively with phosphorus, nitrogen and suspended matter values in the low water phase on the east side of the lake (Fig. 5A). Other cladocerans ( $B$. tubicen, B. longirostris, C. cornuta f. cornuta, C. cornuta f. intermedia, $D$. birgei, $D$. brevireme, D. spinulosum, $M$. micrura and M. minuta) correlated negatively with water alkalinity, dissolved oxygen, $\mathrm{pH}$, temperature and transparency values on the west side of Camargo Lake (Fig. 5A). In relation to the second axis, phosphorus, nitrogen and sus-
A
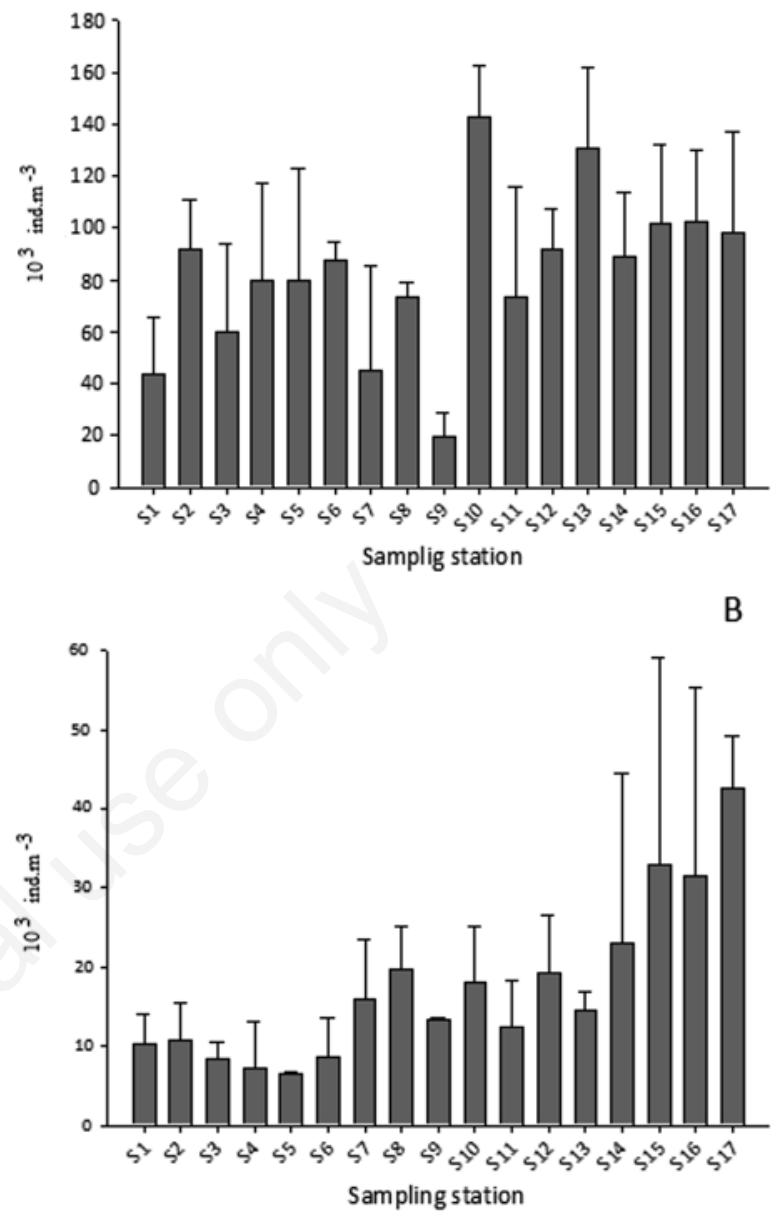

Fig. 3. Total abundance (ind. $\mathrm{m}^{-3}$ ) of cladocerans at sampling stations (S1 to S17) on Camargo Lake during the low (A) and high water (B) phases.

Tab. 1. Means $\pm \mathrm{SD}$ and variables ranges in the water of the 17 stations at dry and rainy periods in Camargo Lake.

\begin{tabular}{|c|c|c|c|c|}
\hline \multirow[t]{2}{*}{ Variables } & \multicolumn{2}{|c|}{ Dry period } & \multicolumn{2}{|c|}{ Rainy period } \\
\hline & \pm SD & Range & $\pm \mathrm{SD}$ & Range \\
\hline Alk (meq L $\left.{ }^{-1}\right)$ & $0.422 \pm 0.011$ & $0.405-0.445$ & $0.398 \pm 0.012$ & $0.367-0.415$ \\
\hline $\mathrm{K}_{25}\left(\mu \mathrm{S} \mathrm{cm}^{-1}\right)$ & $58.8 \pm 0.86$ & $58.1-60.9$ & $62.2 \pm 5.02$ & $55.3-76.6$ \\
\hline $\mathrm{pH}$ & $6.99 \pm 0.09$ & $6.82-7.13$ & $6.83 \pm 0.08$ & $6.70-7.05$ \\
\hline $\mathrm{Z}_{\mathrm{MAX}}(\mathrm{m})$ & $1.16 \pm 0.21$ & $0.85-1.45$ & $3.54 \pm 0.27$ & $3.20-3.95$ \\
\hline Temperature $\left({ }^{\circ} \mathrm{C}\right)$ & $19.5 \pm 1.17$ & $17.8-21.6$ & $24.9 \pm 0.44$ & $24.3-26.5$ \\
\hline $\mathrm{Z}_{\mathrm{DS}}(\mathrm{m})$ & $0.41 \pm 0.06$ & $0.33-0.54$ & $0.61 \pm 0.06$ & $0.53-0.75$ \\
\hline $\mathrm{SM}\left(\mathrm{mg} \mathrm{L}^{-1}\right)$ & $18.8 \pm 4.3$ & $14.8-32.0$ & $11.6 \pm 2.2$ & $6.5-14.3$ \\
\hline $\mathrm{O}_{2}\left(\mathrm{mg} \mathrm{L}^{-1}\right)$ & $6.53 \pm 0.31$ & $5.89-7.02$ & $2.37 \pm 0.68$ & $1.39-3.42$ \\
\hline $\mathrm{TP}\left(\mu \mathrm{g} \mathrm{L}^{-1}\right)$ & $44.5 \pm 6.1$ & $34-55$ & $14.6 \pm 3.1$ & $9-20$ \\
\hline $\mathrm{TN}\left(\mu \mathrm{g} \mathrm{L}^{-1}\right)$ & $181.7 \pm 35.7$ & $134-274$ & $98.8 \pm 31.0$ & $20-132$ \\
\hline Chl-a $\left(\mu \mathrm{g} \mathrm{L}^{-1}\right)$ & $6.8 \pm 1.5$ & $4.7-9.8$ & $6.1 \pm 0.8$ & $4.1-7.2$ \\
\hline
\end{tabular}

Alk, alkalinity; $K_{25}$, conductivity; $Z_{\max }$ maximum depth; $Z_{D S}$, Secchi disk transparency; $S M$, suspended matter; $O_{2}$, dissolved oxygen; TP, total phosphorus; $T N$, total nitrogen; Chl-a, chlorophyll-a. 


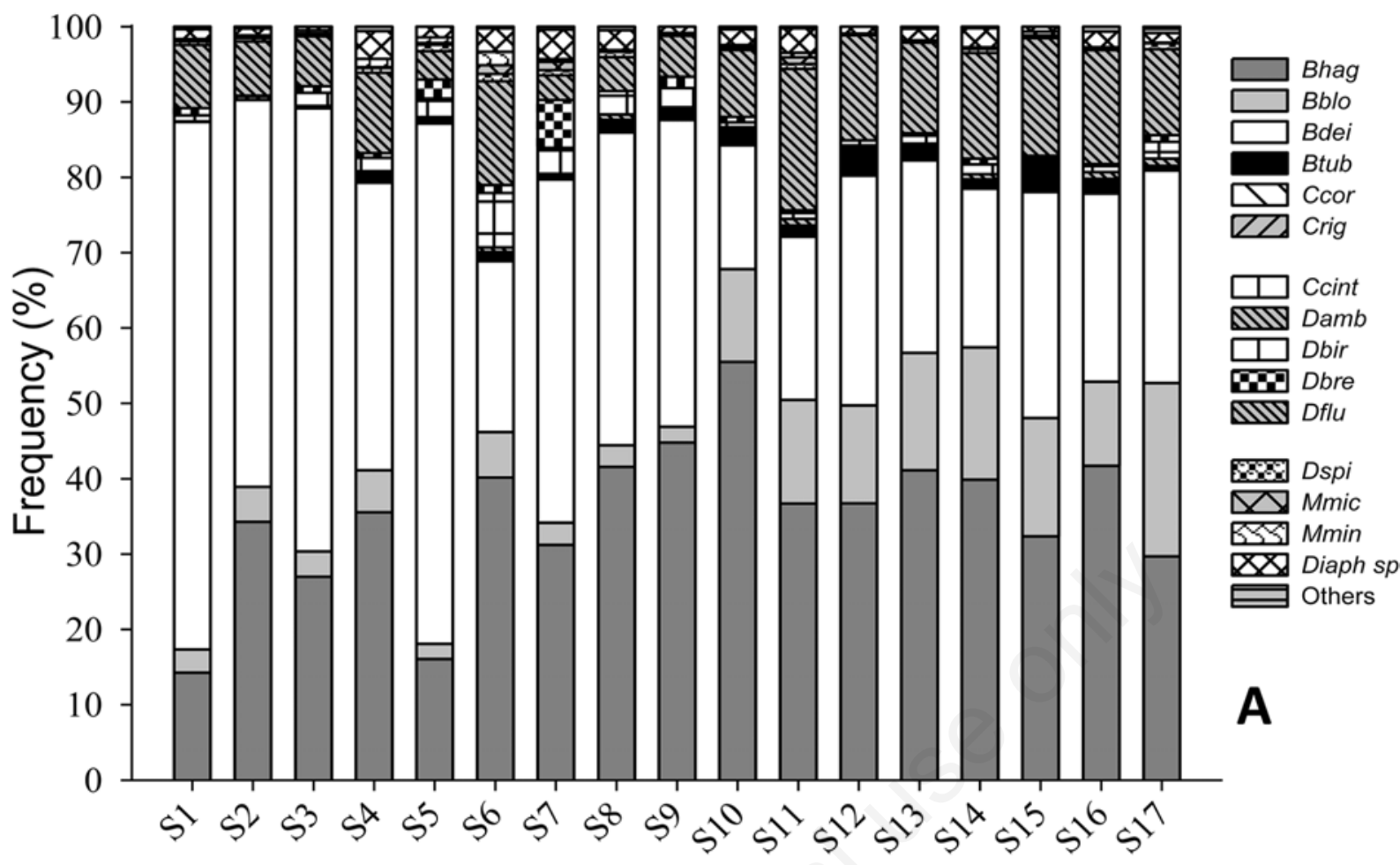

Sampling station

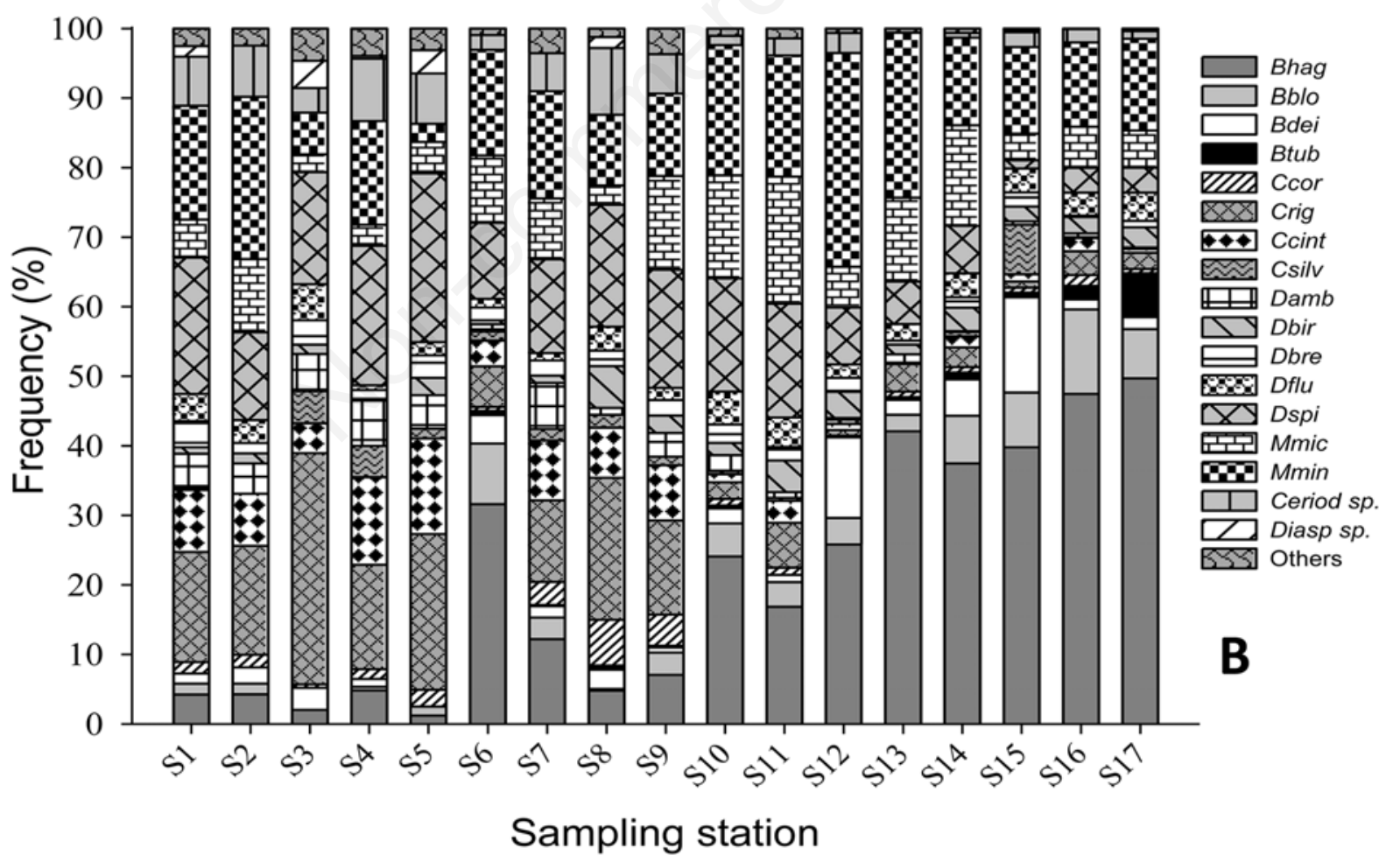

Fig. 4. Relative abundance (\%) of cladoceran taxa at sampling stations (S1 to S17) on Camargo Lake during the low (A) and high water (B) phases (Bhag, Bosmina hagmanni; Bblo, Bosmina longirostris; Btub, Bosmina tubicen; Bdei, Bosminopsis deitersi; Ccor, Ceriodaphnia cornuta f. cornuta; Ccint, Ceriodaphnia cornuta f. intermedia; Crig, Ceriodaphnia cornuta f. rigaudi; Csilv, Ceriodaphnia silvestrii; Damb, Daphnia ambigua; Dbir, Diaphanosoma birgei; Dbre, Diaphanosoma brevireme; Dflu, Diaphanosoma fluviatile; Dspi, Diaphanosoma spinulosum; Mmic, Moina micrura; Mmin, Moina minuta); Ceriod sp, Ceriodaphnia sp; Diasp sp, Diaphanosum sp. 
pended matter values had a positive correlation with $B$. tubicen, B. deitersi, $C$. cornuta f. cornuta, $C$. cornuta f. rigaudi and $D$. fluviatile at stations located predominantly on the east side of the lake. Negative correlations of $B$. hagmanni, B. longirostris, C. cornuta f. intermedia, D. ambigua, D. birgei, D. brevireme, D. spinulosum, $M$. micrura and $M$. minuta with alkalinity, dissolved oxygen, $\mathrm{pH}$, water temperature and water transparency values were recorded on the west side of the lake and at one station on the far east side of the lake. In the high water phase, CV1 presented a positive correlation between total phosphorus and water transparency values at stations located at the front of the connection site of the lake with the river and $B$. hagmanni, B. longirostris, B. tubicen, B. deitersi, D. birgei, $D$. fluviatile, M. micrura, and M. minuta (Fig. 5B). Conversely, C. cornuta f. cornuta, C. cornuta f. intermedia, C. silvestrii, D. brevireme, D. spinulosum and D. ambigua correlated negatively with alkalinity, total suspended matter and depth values at stations on the west side of the lake. CV2 showed a positive correlation between total phosphorus and water transparency values and $B$. hagmanni, B. tubicen, $B$. deitersi, $C$. silvestrii, D. birgei and $M$. micrura at some stations along the maximum length of the lake. Conversely, alkalinity, depth and total suspended matter values correlated negatively with $B$. longirostris, $C$. cornuta f. cornuta, $C$. cornuta f. rigaudi, C. cornuta f. intermedia, D. ambigua, D. brevireme, D. spinulosum and $M$. micrura at stations located on the west side of the lake and at the front site of the connection with the river.

\section{DISCUSSION}

Our data show that species of Ceriodaphnia, Daphnia, Moina, Bosmina, Bosminopsis and genus Diaphanosoma are the most representative in the cladoceran assembly. Variation in relative abundance of species in the two studied periods may have been related to fluctuations in lake volume (Chaparro et al., 2011; Siziba et al., 2011; Panarelli et al., 2014). Variations in the river's hydrologic level and the lateral introduction of water to the lake induce a dilution effect during the potamophase and a concentration effect on the abundance of cladocerans during the limnophase (Panarelli et al., 2014). Variation in lake size may determine conditions that are either favorable or unfavorable to the cladoceran assembly species, for example, connection sites between the marginal lake and river (Cottenie and De Meester, 2003), degree of connectivity between lentic and lotic ecosystems (Alves et al., $2005)$ and complexity of habitats in the littoral zones (Balayla and Moss, 2003).

Variations in cladoceran abundances were characteristic of heterogeneous horizontal distribution and a concentration of most organisms was recorded at sampling stations near the site of connection to the river and on the east side of the lake in both periods. A peculiar spatial distribution of cladocerans showed that the majority of the species inhabiting Camargo Lake present a patchy distribution, with the exceptions of B. longirostris and D. fluviatile.

In Camargo Lake, predation is probably a non-control-

Tab. 2. Linear regression of the means crowding and mean population densities of Cladocera at two periods in Camargo Lake and patterns of species distribution.

\begin{tabular}{|c|c|c|c|c|c|c|c|c|c|c|}
\hline \multirow[t]{2}{*}{ Species } & \multicolumn{5}{|c|}{ Dry period } & \multicolumn{3}{|c|}{ Rainy period } & \multirow[b]{2}{*}{$\mathrm{n}$} & \multirow[b]{2}{*}{ DP } \\
\hline & b & r & $\mathbf{P}$ & $\mathrm{n}$ & DP & b & $r$ & $\mathbf{P}$ & & \\
\hline Cladocera assembly & 0.88 & 0.89 & $\mathrm{P}<0.05$ & 17 & $\mathrm{U}$ & 1.36 & 0.84 & $\mathrm{P}<0.05$ & 17 & A \\
\hline B. hagmanni & 1.07 & 0.95 & $\mathrm{P}<0.05$ & 17 & A & 1.47 & 0.88 & $\mathrm{P}<0.05$ & 17 & A \\
\hline B. longirostris & -5.55 & -0.33 & $\mathrm{P}>0.05$ & 17 & $\mathrm{U}$ & -18.82 & -0.19 & $\mathrm{P}>0.05$ & 16 & $\mathrm{U}$ \\
\hline B. tubicen & 1.46 & 0.90 & $\mathrm{P}<0.05$ & 16 & A & 2.40 & 0.78 & $\mathrm{P}<0.05$ & 16 & A \\
\hline B. deitersi & 1.48 & 0.80 & $\mathrm{P}<0.05$ & 17 & A & 1.97 & 0.99 & $\mathrm{P}<0.05$ & 10 & A \\
\hline C. cornuta f. cornuta & 3.30 & 0.98 & $\mathrm{P}<0.05$ & 4 & A & 1.51 & 0.95 & $\mathrm{P}<0.05$ & 17 & A \\
\hline C. cornuta f. rigaudi & - & - & - & - & - & 1.54 & 0.90 & $\mathrm{P}<0.05$ & 17 & A \\
\hline C. cornuta f. intermedia & - & - & - & - & - & 1.56 & 0.89 & $\mathrm{P}<0.05$ & 17 & A \\
\hline C. silvestrii & - & - & - & - & - & 3.01 & 0.99 & $\mathrm{P}<0.05$ & 16 & A \\
\hline D. ambigua & 1.48 & 0.88 & $\mathrm{P}<0.05$ & 13 & A & 1.47 & 0.86 & $\mathrm{P}<0.05$ & 17 & A \\
\hline D. birgei & 1.36 & 0.94 & $\mathrm{P}<0.05$ & 17 & A & 1.20 & 0.76 & $\mathrm{P}<0.05$ & 16 & A \\
\hline D. brevireme & 2.32 & 0.88 & $\mathrm{P}<0.05$ & 15 & A & 1.36 & 0.58 & $\mathrm{P}<0.05$ & 17 & A \\
\hline D. fluviatile & 0.99 & 0.89 & $\mathrm{P}<0.05$ & 17 & $\mathrm{U}$ & 1.26 & 0.88 & $\mathrm{P}<0.05$ & 17 & A \\
\hline D. spinulosum & 1.15 & 0.71 & $\mathrm{P}<0.05$ & 17 & A & 1.18 & 0.82 & $\mathrm{P}<0.05$ & 17 & A \\
\hline M. micrura & 2.28 & 0.85 & $\mathrm{P}<0.05$ & 13 & $\mathrm{~A}$ & 1.75 & 0.71 & $\mathrm{P}<0.05$ & 17 & $\mathrm{~A}$ \\
\hline M. minuta & 2.79 & 0.97 & $\mathrm{P}<0.05$ & 17 & A & 1.33 & 0.87 & $\mathrm{P}<0.05$ & 17 & A \\
\hline
\end{tabular}

$D P$, distribution patterns; $b$, angular coefficient; $r$, linear coefficient; $n$, stations number of specie occurrence; $U$, uniform; A, aggregate. 

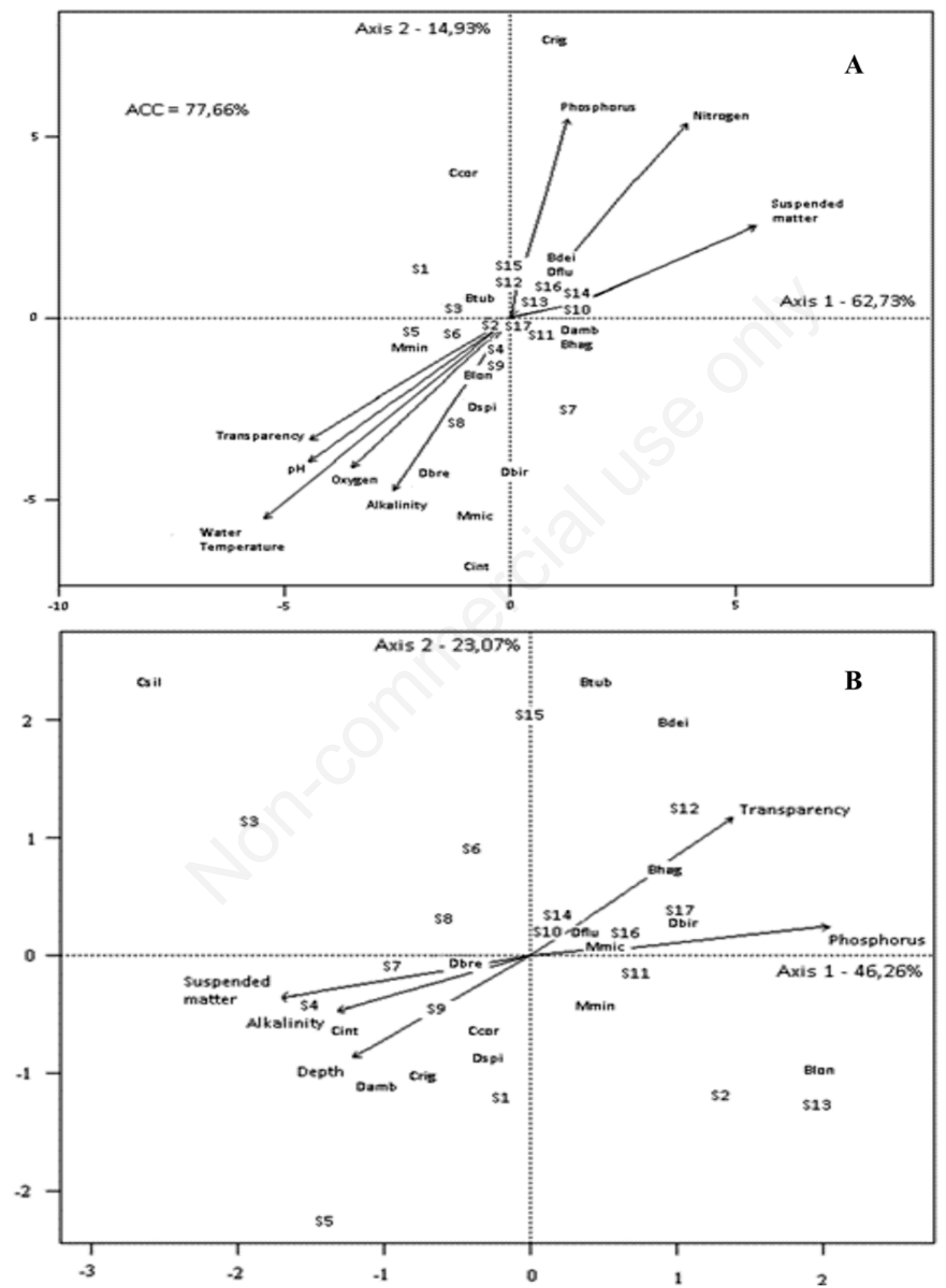

Fig. 5. Canonical correspondence analysis (CCA) of the relationships between cladoceran species abundance on Camargo Lake and abiotic variables and sampling stations in the low (A) and high water phases (B) (Acronyms of cladoceran species, see legend of Fig. 4). 
ling factor of cladoceran distribution due to the low occurrence of predators, such as Chaoborus (Zerlin and Henry, 2014), and a low density of fish larvae (Suiberto, 2005). A restrictive condition for predation on cladocerans by fish larvae and Chaoborus is water transparency (Arcifa et al., 1992; Arcifa, 1999). Relatively low water transparency values were found in Camargo Lake during the two periods, a situation which is adverse to cladoceran predation.

In the high water phase, the distribution of the sampling sites evidenced one group shaped by the stations located on the east side of the lake, distant from the site of the connection to the river. The lowest suspended matter concentration and the highest water transparency on the east side of the lake were probably the main factors causing the grouping of a great number of cladocerans. On the west side of the lake, the shallowest side, wind action may re-suspend inorganic matter from the bottom, reducing water transparency and affecting the abundance of cladoceran. The introduction of allochthonous matter by the river during the potamophase was very low due to the presence of Echinochloa polystacha, as it reduced sediment entrapment efficiency (Henry, 2009). Concerning the factors that affect cladoceran distribution at specific level, a discrepancy was observed between the two periods. In the dry period, $B$. deitersi, $C$. cornuta f. rigaudi and $D$. fluviatile correlated positively with suspended matter and total nitrogen and phosphorus on the east side of the lake (S10 to S16, except S17). Macroelements, such as nitrogen and phosphorus, together with suspended matter, are potential nutritional factors for the lake and promote a high abundance of cladocerans. Although no significant variation was found for chlorophyll-a, an index of phytoplankton biomass, on this side of the lake, suspended matter from organic detritus might be an alternative food resource to algae (Fileto et al., 2010). Conversely, D. brevireme, D. spinulosum, D. birgei, $B$. longirostris, Ceriodaphnia cornuta f. intermedia, M. micrura and M. minuta correlated negatively with Secchi disk transparency, water temperature, dissolved oxygen, $\mathrm{pH}$ and alkalinity at the shallowest stations ( $\mathrm{S} 2$ to S9, except S1 and S7). Environmental factors from this region of the lake were decisive in determining the low abundances of these species. During the limnophase, wind may re-suspend sediment with a predominance of inorganic fraction from the bottom of Camargo Lake, which may affect the filtration apparatus of cladocerans (Geller and Muller, 1981) and reduce food ingestion and, thus, the proliferation of the last six species.

The abundance of species at stations $\mathrm{S} 1$ to S6, S8, S9 and $\mathrm{S} 17$ in the dry period correlated to water temperature and dissolved oxygen, two factors which regulate the cladoceran life history. Low values of these two variables may limit cladoceran survival, reduce growth rates, mating, food ingestion, swimming speed and may affect mi- gration (Sarma et al., 2005; Bunioto and Arcifa, 2007).

Correlation between water transparency and B. longirostris, C. cornuta f. intermedia, D. birgei, D. brevireme, D. spinulosum, $M$. micrura and $M$. minuta was related to a greater sampling station depth and greater concentrations of suspended organic and inorganic matter from S1 to S6. Cladoceran filtration and survival rates are dependent on the quality and concentration of suspended matter in water (Ferrão-Filho et al., 2005; Fileto et al., 2010). Variation in the abundance of the species above from S1 to S6 and at stations S8, S9 and S17 correlated to water transparency may be affected by fluctuations in the amounts of suspended organic and inorganic matter. Inorganic suspended matter can be harmful to cladocerans, since it may adhere to and obstruct their respiratory and natatory apparatuses (Mourelatos and Lacroix, 1990; Macedo and Pinto-Coelho, 2000). A high organic content in suspended matter is a sign of food richness, shaped by phytoplankton and organic aggregated detritus (Vilar et al., 2014). Great food availability may increase the breeding capacity and promote growth and an increase in abundance of cladocerans (Fileto et al., 2010).

Water $\mathrm{pH}$ and alkalinity affect phytoplankton and influence zooplankton indirectly. Neves et al. (2003) found great abundances of $C$. cornuta $\mathrm{f}$. cornuta, D. spinulosum and M. minuta in marginal lakes of the Cuiabá River (Mato Grosso, Brazil), but no variation on water $\mathrm{pH}$ between lakes was detected. Conversely, Choueri et al. (2005) related low abundance of bosminideans to high water $\mathrm{pH}$ values in the Ivinheima floodplain (Mato Grosso do Sul and Paraná, Brazil), but with similar contents of chlorophyll- $a$. Although chlorophyll- $a$ (total pigments) had no correlation with any cladoceran species, an indirect positive effect was evident, since water $\mathrm{pH}$ and alkalinity values were favorable to an increase in chlorophyll- $a$ at the sampling stations.

A positive correlation between total phosphorus and Bosminidae species, D. birgei, D. fluviatile and the Moina genus during the high water phase may be explained by a possible nutritional relationship between cladocerans and phytoplankton, considering that phosphorus is an important element for algae growth (Elser et al., 2001; Fileto et al., 2004). Despite a lack of correlation with cladoceran abundances, chlorophyll- $a$, as well as phosphorus concentrations, was the highest at stations S2 and from S10 to S17. High amounts of chlorophyll-a at these stations can be considered to be a potential food resource, since high richness values of Chlorophyceae and Cryptophyceae algae have been found in Camargo Lake (Granado and Henry, 2014). Both types of algae are highly palatable to cladocerans (Mourelatos and Lacroix, 1990; Fileto et al., 2004; Pagano, 2008).

Considering water transparency and suspended matter, CCA results indicated a similar trend in both the high and 
low water phases, since the variables can be seen in opposite sides of the figure. Such data may be related to the location of the sampling stations in relation to the lake connection to the river. The highest water transparency values were observed at stations located in the transition and the deepest zones of Camargo Lake (from S9 to S17) and the highest suspended matter concentrations in the shallowest zone (from S1 to S7). At stations near the site of connection of the lake to the river, high allochthonous particulate matter and organic contribution from the littoral zone of the lake favored the correlation found.

Both wind and lake volume variations may affect the seasonal hydrodynamics of a lacustrine ecosystem and determine the shape of cladoceran patches. George and Winfield (2000) attributed the variations in horizontal distribution of cladoceran patches to water movement, wind effect and lake morphometry. Thackeray et al. (2006) asserted that these variables may influence the horizontal distribution of zooplankton patches and thus promote changes in abiotic factors, such as temperature and dissolved oxygen. In Camargo Lake, wind also appears to be an important factor in determining the spatial distribution of cladoceran assemblies. A concentration of individuals was observed at the stations on the east side of the lake in the two periods studied and a higher number of organisms occurred in the dry period, when the daily wind mean speed was also higher.

Wind is an aging factor to water mixing, reducing transparency and re-suspending inorganic matter from the bottom. Wind blowing on the shallow side of Camargo Lake (S1 to S7) may introduce inorganic matter from the bottom to the water column and affect cladoceran filtration rates. At the stations located on the east side of $\mathrm{Ca}$ margo Lake, the effect of re-suspension is minor, considering that they are the deepest sites and more distant from the connection to the river. To the low water turbulence and low amount of suspended matter in this region of the lake we may attribute the correlation between water transparency and the abundance of bosmideans, Moina genus and, D. birgei and D. fluviatile.

\section{CONCLUSIONS}

In conclusion, wind was an important factor in determining the predominance of most of the observed cladoceran species during the two periods studied on the east side of Camargo Lake; however, the aggregation index value revealed a uniform distribution for the assembly in the low water phase. Most cladoceran species presented an aggregated pattern, except $B$. longirostris in both periods and D. fluviatile in the low water phase, but the patch distribution patterns differed in the dependence of the cladoceran species. Nutritional and environmental factors were determinants of heterogeneous distribution of cladocerans at specific level in the lake.

\section{ACKNOWLEDGMENTS}

RMC received a scholarship from CAPES. The authors are grateful to Gilmar Perbiche-Neves and Maria Stela Maioli Castilho-Noll for their comments, Laerte José da Silva for the English revision and to two anonymous reviewers for their suggestions and criticisms.

\section{REFERENCES}

Adamczuk M, Mieczan T, 2013. Spatial distribution of broodbearing females of limnetic species of Cladocera. C. R. Biol. 336:457-465.

Alves GM, Velho LFM, Lansac-Tôha FA, Robertson B, Bonecker CC, 2005. Effect of the connectivity on the diversity and abundance of cladoceran assemblages in lagoons of the upper Paraná river floodplain. Acta Limnol. Bras. 17:317-327.

Arcifa MS, 1999. [Lago Monte Alegre: uma visão sobre a estrutura e hipótese de funcionamento], p. 55-76. In: R. Henry (ed.), [Ecologia de reservatórios: estrutura, função e aspectos sociais]. Gráfica Tipomic, Botucatu.

Arcifa MS, Gomes EAT, Meschiatti AJC, 1992. Composition and fluctuations of the zooplankton of a tropical Brazilian reservoir. Arch. Hydrobiol. 123:479-495.

Balayla DJ, Moss B, 2003. Spatial patterns and population dynamics of plant-associated microcrustacea (Cladocera) in an English shallow lake (Little Mere, Cheshire). Aquat. Ecol. 37:417-435.

Bernot RJ, Dodds WK, Quist MC, Guy CS, 2004. Spatial and temporal variability of zooplankton in a great plains reservoir. Hydrobiologia 525:101-112.

Bunioto TC, Arcifa MS, 2007. Effects of food limitation and temperature on cladoceran from a tropical Brazilian lake. Aquat. Ecol. 41:569-578.

Chaparro G, Marinone MC, Lombardo RJ, Schiaffino R, Guimarães A de S, O'Farrell I, 2011. Zooplankton succession during the extraordinary drought-flood cycles: a case study in a South American floodplain lake. Limnologica 41:373-381.

Choueri RB, Bonecker CC, Dias JD, 2005. Spatial and temporal density variation of microcrustacean assemblages in different systems of the upper Paraná River floodplain (PR/MS Brazil). Acta Sci. Biol. Sci. 27:243-250.

Cottenie K, De Meester L, 2003. Connectivity and cladoceran species richness in a metacommunity of shallow lakes. Freshwater Biol. 48:823-832.

Elmoor-Loureiro LMA, 1997. [Manual de identificação de cladóceros límnicos do Brasil].[Book in Portuguese]. Universa, Brasilia: $156 \mathrm{pp}$.

Elmoor-Loureiro LMA, 2007. Phytophilous cladocerans (Crustacea, Anomopoda and Ctenopoda) from Paranã River Valley, Goiás, Brazil. Rev. Bras. Zool. 24:344-352.

Elmoor-Loureiro LMA, Mendonça-Galvão L, Padovesi-Fonseca C, 2004. New cladoceran records from Lake Paranoá, Central Brazil. Braz. J. Biol. 63:415-422.

Elser JJ, Hayakawa O, Urabe J, 2001. Nutrient limitation reduces food quality for zooplankton: Daphnia response to seston phosphorus enrichment. Ecology 82:898-893.

Ferrão-Filho AS, Arcifa MS, Fileto C, 2005. Influence of seston quantity and quality on growth of tropical cladocerans. Braz. J. Biol. 65:77-89. 
Fileto C, Arcifa MS, Ferrão-Filho AS, Silva LHS, 2004. Influence of phytoplankton fractions on growth and reproduction of tropical cladocerans. Aquat. Ecol. 38:503-514.

Fileto C, Henry R, Arcifa MS, Ferreira RAR, 2010. Effects of temperature, sestonic algae features, and seston mineral content on cladocerans from a tropical marginal lake of a Brazilian river. Ann. Limnol.-Int. J. Lim. 46:135-147.

Folt CL, Burns CW, 1999. Biological drivers of zooplankton patchiness. Trends Ecol. Evol. 14:300-305.

Geller W, Muller H, 1981. The filtration apparatus of Cladocera: filter mesh-sizes and their implication on food selectivity. Oecologia 49:316-321.

George DG, Winfield IJ, 2000. Factors influencing the spatial distribution of zooplankton and fish in Loch Ness, UK. Freshwater Biol. 43:557-570.

Goltermann HL, Clymo RS, Ohnstad MA, 1978. Methods for physical and chemical analysis of freshwater, $2^{\text {nd }}$ ed. Blackwell, Oxford: 213 pp.

Granado DC, Henry R, 2012. Changes in abiotic characteristics of water in the Paranapanema river and three lateral lagoons at mouth zone of the Jurumirim Reservoir, São Paulo, Brazil during the flood period. Lat. Amer. J. Aquat. Res. 40:79-89.

Granado DC, Henry R, 2014. Phytoplankton community response to hydrological variations in oxbow lakes with different levels of connection to a tropical river. Hydrobiologia 721:223-238.

Henry R, 2005. The connectivity of the Paranapanema River with two lateral lakes in its mouth zone into the Jurumirim Reservoir. Acta Limnol. Bras. 17:57-69.

Henry R, 2009. Annual changes in sediment entrapment efficiency in lakes lateral to a river (Paranapanema River, São Paulo, Brazil). Acta Limnol. Bras. 21:25-34.

Hudec I, 2000. Subgeneric differentiation within Kurzia (Crustacea: Anomopoda: Chydoridae) and a new species from Central American. Hydrobiologia 421:165-178.

Junk WJ, Piedade MTF, Lourival R, Wittmann F, Kandus P, Lacerda LD, Bozelli RL, Esteves FA, Nunes da Cunha C, Maltchik L, Schongart J, Schaeffer-Novelli Y, Agostinho AA, 2014. Brazilian wetlands: their definition, delineation, and classification for research, sustainable management, and protection. Aquat. Conserv. 24:5-22.

Korinek V, 1987. Revision of three species of the genus Diaphanosoma Fischer, 1850. Hydrobiologia 145:35-45.

Lazareva V.I., Stolbunova VN, Mineeva NM, Zhdanova SM, 2013. Features of the structure and spatial distribution of plankton in the Sheksna reservoir. Inland Water Biol. 6:211-219.

Lansac-Tôha FA, Bonecker CC, Velho LFM, Simões NR, Dias JD, Alves GM, Takahashi EM, 2009. Biodiversity of zooplankton communities in the Upper Paraná River floodplain: interannual variation from long-term studies. Braz. J. Biol. 69:539-549.

Lloyd M, 1967. Mean crowding. J. Anim. Ecol. 36:1-30.

Macedo CF, Pinto-Coelho R, 2000. [Taxas de filtração de Daphnia laevis e Moina micrura em relação às clorofícieas Scenedesmus quadricauda e Ankistrodesmus gracilis].[Article in Portuguese]. Acta Limnol. Bras. 12:1-10.

Malone BJ, McQueen DJ, 1983. Horizontal patchiness in zooplankton in two Ontario kettle lakes. Hydrobiologia 99:101-124.

Mitchell BD, Williams WD, 1982. Population dynamics and production of Daphnia cavinata (King) and Simocephalus exspinosus (Koch) in waste stabilization ponds. Aust. J. Mar. Fresh. Res. 33:837-864.

Moschini-Carlos V, Pompêo MLM, Henry R, 1998. [Caracterização limnológica de uma baía marginal ao rio Paranapanema (zona de desembocadura na represa de Jurumirim, SP)].[Article in Portuguese]. Acta Limnol. Bras. 10:1-19.

Mourelatos S, Lacroix G, 1990. In situ filtering rates of Cladocera: effect of body length, temperature, and food concentration. Limnol. Oceanogr. 35:1101-1111.

Neves IF, Rocha O, Roche, KF, Pinto AA, 2003. Zooplankton community structure of two marginal lakes of the river Cuiabá (Mato Grosso, Brazil) with analysis of Rotifera and Cladocera diversity. Braz. J. Biol. 63:329-343.

Orlova-Bienkowskaja MJ, 1998. A revision of the cladoceran: a genus Simocephalus (Crustacea, Daphniidae). Bull. Nat. Hist. Mus. 64:1-62.

Pagano M, 2008. Feeding of tropical cladocerans (Moina micrura, Diaphanosoma excisum) and rotifer (Brachionus calyciflorus) on natural phytoplankton: effect of phytoplankton size-structure. J. Plankt. Res. 30:401-414.

Panarelli EA, Hoffmann P, Casanova SMC, Mortari RC, Henry R, 2014. [O efeito da conexão e desconexão entre rio e lagoa para assembleia de Cladocera: um estudo de caso na lagoa do Camargo], p. 227-241. In: R. Henry (ed.), ]Represa de Jurumirim: ecologia, modelagem e aspectos sociais].[Book in Portuguese]. Holos Editora, Ribeirão Preto.

Pinel-Alloul B, 1995. Spatial heterogeneity as a multiscale characteristic of zooplankton community. Hydrobiologia 300/301:17-42.

Pinel-Alloul B, Methot G, Malinsky-Rushansky NZ, 2004. A short-term study of vertical and horizontal distribution of zooplankton during thermal stratification. Hydrobiologia 526:85-98.

Pompeo MLM, Henry R, Moschini-Carlos V, 1999. [Ecologia de Echinochloa polystachya na represa de Jurumirim], p. 737-767. In: R. Henry (ed.) [Ecologia de reservatórios: estrutura, função e aspectos sociais].[Book in Portuguese]. Gráfica Tipomic, Botucatu.

Sarma SSS, Nandini S, Gulati RD, 2005. Life history strategies of cladocerans: comparisons of tropical and temperate taxa. Hydrobiologia 542:315-333.

Siziba N, Chimbari MJ, Masundire H, Mosepele K, 2011. Spatial and temporal variations of microinvertebrates across temporary floodplains of the lower Okacango Delta, Botswana. Phys. Chem. Earth 36:939-948.

Smirnov NN, 1996. Cladocera: the Chydorinae and Sayciinae (Chydoridae) of the world. SPB Academic Publ., Amsterdam: $197 \mathrm{pp}$.

Suiberto MR, 2005. [Distribuição especial e temporal do ictioplâncton em lagoas laterais e no rio Paranapanema na sua zona de desembocadura na represa de Jurumirim, SP].[PhD Thesis in Portuguese]. Universidade Estadual Paulista, Botucatu.

Thackeray SJ, George DG, Jones, RI, Winfield IJ, 2006. Statistical quantification of the effect of thermal stratification on patterns of dispersion in a freshwater zooplankton community. Aquat. Ecol. 40:23-32.

Thomaz SM, Bini LM, Bozelli RL, 2007. Floods increase similarity among habitats in river floodplain systems. Hydrobiologia 579:1-13. 
Valderrama JG, 1981. The simultaneous analysis of total nitrogen and phosphorus in natural waters. Mar. Chem. 10:109-122.

Vilar AG, Vonk JA, Bichebois S, Van Dam H, Admiraal W, Van der Geest H, 2014. Suspended organic particles drive the development of attached algal communities in degraded peats. Hydrobiologia 744:211-221.
Wetzel, RG, Likens GE, 2000. Limnological analyses, $3^{\text {rd }}$ ed. Springer Science+Business Media, New York: 429 pp.

Zar JH, 1996. Biostatistical analysis. Prentice-Hall, Upper Saddle River: $662 \mathrm{pp}$.

Zerlin RA, Henry R, 2014. Does water level affect benthic macro-invertebrates of a marginal lake in a tropical riverreservoir transition zone? Braz. J. Biol. 74:408-419. 